Final Report

FHWA/IN/JTRP-2005/25

\title{
REMEDIATION OF AROMATIC HYDROCARBONS IN LOW PERMEABILITY SOILS: UPDATING THE REMEDIATION DECISION TREE (SYNTHESIS STUDY)
}

\author{
By \\ Inez Hua \\ Principal Investigator \\ Associate Professor \\ and \\ Andy Hopf \\ Graduate Research Assistant \\ School of Civil Engineering \\ Purdue University \\ Joint Transportation Research Program \\ Project No. C-36-68X \\ File No. 4-7-24 \\ SPR-2924 \\ Conducted in cooperation with the \\ Indiana Department of Transportation and \\ the U.S. Department of Transportation \\ Federal Highway Administration
}

The contents of this paper reflect the views of the authors, who are responsible for the facts and the accuracy of the data presented herein, and do not necessarily reflect the official views or policies of the Federal Highway Administration and the Indiana Department of Transportation, nor do the contents constitute a standard, specification, or regulation.

Purdue University

West Lafayette, Indiana

February 2006 


\section{TECHNICAL Summary}

INDOT Research

Technology Transfer and Project Implementation Information

\section{Remediation of Aromatic Hydrocarbons in Low Permeability Soils: Updating the Remediation Decision Tree (Synthesis Study)}

\section{Introduction}

A large number of in situ remediation technologies and treatment trains have been investigated for the removal and destruction of organic contaminants in soil and groundwater. These techniques have been examined at the laboratory, pilot scale, and fullscale. In general, these technologies are either extractive or destructive. Extractive technologies remove contaminant mass whereas destructive technologies destroy contaminant mass in situ. Selected examples of technologies include in situ oxidation or reduction, bioremediation, natural attenuation, air sparging, enhanced dissolution, and excavation. Many other technologies and approaches have been explored.

Because of the large number of technologies, the very different types of contaminants to which these technologies are applicable, and the wide range of field conditions, it can be difficult to choose an optimal technology for a specific site. Sorting and prioritizing the various factors which contribute to the success of a particular clean-up can be daunting. Furthermore, non-technical factors, such as those in the legal, political, or financial realm, may also influence technology choices. Aromatic hydrocarbons, in particular benzene, pose a formidable clean-up challenge in part because the clean-up goal is so stringent. Most in situ treatment methods are effective in permeable soil. However, much of Indiana soil is low-permeability, so applicability of these methods is limited. For example, there are INDOT sites where contamination has migrated to spread over a large area of clayey soil. In one case, the contamination followed a building foundation. In some cases, very thin sand seams allow migration over time but do not allow the rapid movement needed for air-sparging or injection to be effective. One of the few currently viable options is excavation and disposal.

\section{Findings}

Decision-support tools were developed for use by INDOT staff involved with site remediation. A series of decision-trees were produced, based on the synthesis and analysis of literature data, and case studies of successfully remediated sites. Each decision-tree was designed such that the user will answer a series of questions in order to determine whether or not to apply a certain remediation technology at a site. The questions were formulated by considering the remediation data obtained from the literature, and other information. Questions address physical and chemical characteristics of a specific pollutant, site characteristics and local conditions, and regulatory issues. In addition, documentation for the decision trees has been developed for user guidance. Technologies incorporated into the decision tree analysis include: electrical resistance heating, trench and gate, bioslurping, electrokinetic, soil and vapor extraction combined with pneumatic fracturing, 
bioremediation combined with pneumatic fracturing.

Another tool that was developed was a searchable database of remediated sites. Sites were chosen on the basis of their similarity to INDOT sites. Information regarding site conditions, contaminants, and remediation endpoints were obtained and included in the database. The subsurface of many sites in the database are glacial till. They vary from clays to silty clays with lenses of sand and gravel. All sites in the database are located in low permeability soils $\left(\mathrm{k}<10^{-5} \mathrm{~cm} / \mathrm{s}\right)$. The goal of the sites evaluated at the field scale was to remediate the soil and groundwater to regulatory levels. Information for the development of these tools was collected from an extensive literature survey, and available case files on remediated sites.

\section{Implementation}

The decision support tools developed in this synthesis study would be most useful to staff in the Division of Environment, Planning and Engineering. Specifically, any projects related to contaminated site remediation would benefit from use of the decision trees to analyze potential remediation technologies. The database of remediated sites will yield information about site characteristics and the success of certain types of technologies. The decision-trees will provide information about the applicability of technologies given constraints at the specific site. For example, when standard excavation of contaminated soil is not feasible or cost-effective, other technologies (in situ) may need to applied. Furthermore, for sites that exhibit low-permeability (including most sites in Indiana), these tools will help prioritize among possible technologies.

\section{Contacts}

For more information:

Prof. Inez Hua

Principal Investigator

School of Civil Engineering

Purdue University

West Lafayette IN 47907

Phone: (765) 494-2409

Fax: (765) 496-1988

E-mail: hua@ecn.purdue.edu
Indiana Department of Transportation

Division of Research

1205 Montgomery Street

P.O. Box 2279

West Lafayette, IN 47906

Phone: (765) 463-1521

Fax: (765) 497-1665

\section{Purdue University}

Joint Transportation Research Program

School of Civil Engineering

West Lafayette, IN 47907-1284

Phone: (765) 494-9310

Fax: (765) 496-7996

E:mail: jtrp@ecn.purdue.edu

http://www.purdue.edu/jtrp 


\begin{tabular}{|c|c|c|}
\hline $\begin{array}{l}\text { 1. Report No. } \\
\text { FHWA/IN/JTRP-2005/25 }\end{array}$ & 2. Government Accession No. & 3. Recipient's Catalog No. \\
\hline \multirow{2}{*}{\multicolumn{2}{|c|}{$\begin{array}{l}\text { 4. Title and Subtitle } \\
\text { Remediation of Aromatic Hydrocarbons in Low Permeability Soils: Updating } \\
\text { the Remediation Decision Tree (Synthesis Study) }\end{array}$}} & $\begin{array}{l}\text { 5. } \text { Report Date } \\
\text { February } 2006\end{array}$ \\
\hline & & 6. Performing Organization Code \\
\hline \multicolumn{2}{|l|}{$\begin{array}{l}\text { 7. Author(s) } \\
\text { Inez Hua and Andy Kopf }\end{array}$} & $\begin{array}{l}\text { 8. Performing Organization Report No. } \\
\text { FHWA/IN/JTRP-2005/25 }\end{array}$ \\
\hline \multirow{2}{*}{\multicolumn{2}{|c|}{$\begin{array}{l}\text { 9. Performing Organization Name and Address } \\
\text { Joint Transportation Research Program } \\
1284 \text { Civil Engineering Building } \\
\text { Purdue University } \\
\text { West Lafayette, IN 47907-1284 }\end{array}$}} & 10. Work Unit No. \\
\hline & & $\begin{array}{c}\text { 11. Contract or Grant No. } \\
\text { SPR-2924 }\end{array}$ \\
\hline \multirow{2}{*}{\multicolumn{2}{|c|}{$\begin{array}{l}\text { 12. Sponsoring Agency Name and Address } \\
\text { Indiana Department of Transportation } \\
\text { State Office Building } \\
100 \text { North Senate Avenue } \\
\text { Indianapolis, IN } 46204\end{array}$}} & $\begin{array}{l}\text { 13. Type of Report and Period Covered } \\
\text { Final Report }\end{array}$ \\
\hline & & 14. Sponsoring Agency Code \\
\hline \multicolumn{3}{|l|}{ 15. Supplementary Notes } \\
\hline
\end{tabular}

16. Abstract

Because of the large number of technologies for in situ remediation, the very different types of contaminants to which these technologies are applicable, and the wide range of field conditions, it can be difficult to choose an optimal technology for a specific site. Sorting and prioritizing the various factors which contribute to the success of a particular clean-up can be daunting. Furthermore, non-technical factors, such as those in the legal, political, or financial realm, may also influence which technology is ultimately chosen. Most in situ treatment methods are effective in permeable soil. However, much of Indiana soil is low-permeability, so applicability of these methods is limited. One of the few currently viable options is massive (and expensive) excavation and disposal.

The purpose of the study is to develop decision-support tools for use by INDOT staff involved with site remediation. The decision-support tools include remediation decision-trees for choosing technologies or combinations of technologies appropriate for specific types of sites, including sites with low-permeability soil. In order to develop decisiontrees, it is necessary to conduct a comprehensive analysis of remediation technologies, with a focus on investigations of aromatic hydrocarbons and low-permeability soils. An additional objective is to construct a database of remediated sites in the region. The types of sites will be screened so that they are as similar as possible to sites of interest to INDOT. In particular, information from sites that have been successfully remediated will be chosen. This project will expand the scientific basis for the development and application of innovative treatment for contaminated sites owned and operated by INDOT. Potential benefits include a more effective means of remediating benzene and other fuel hydrocarbons without having to excavate and dispose of contaminated soil. The use of a remediation decision tree may decrease the time needed to choose an effective technology.

17. Key Words

In situ remediation, groundwater, soil, low-permeability, gasoline, decision tree
18. Distribution Statement

No restrictions. This document is available to the public through the National Technical Information Service, Springfield, VA 22161
19. Security Classif. (of this report)

Unclassified
20. Security Classif. (of this page)

Unclassified
21. No. of Pages

49 


\section{Acknowledgements}

This research project was sponsored by the Indiana Department of Transportation (INDOT) in cooperation with the Federal Highway Administration through the Joint Transportation Research Program. The authors would like to thank the Project Administrator, Dr. Barry K. Partridge, and the Study Advisory Committee members, Ben Lawrence, Anthony DeSimone, and Tom Vanderpool for their valuable assistance and guidance. Thanks are also given to the staff at the Indiana Department of Environmental Management (IDEM) specifically Mike Sickels. 


\section{Chapter 1. Introduction and Problem Statement}

\section{Table of Contents}

1.1. Background Information and Problem Statement

1.2. Research Scope and Approach

1.3. Objectives and Purpose Of The Study

\section{Chapter 2. Literature Survey}

2.1 Introduction

2.2 Subsurface Indiana

2.3 Contaminant Removal

2.4 Decision Making

2.5 Technologies

2.6 Sources and Quality of Literature Data

2.7 Conclusion

Chapter 3. Regulatory Discussion on Technology Use

3.1 Introduction

3.2 Soil Fracturing

3.3 Trench and Gate

3.4 Thermal Technologies

3.5 Barometric Pumping

3.6 Alternative Technologies

Chapter 4. Remediate Site Database and Decision Tree

4.1 SVE and Pneumatic Fracturing Decision Tree

4.2 Trench and Gate Decision Tree

4.3 Bioremediation Decision Tree

4.4 Excavation Decision Tree

4.5 Decision Trees Applied to Test Cases

43

4.6 Summary of Database

48 


\section{List of Tables}

\section{Chapter 2}

Table 2-1: Overview of Technologies

Table 2-2: Journal Impact Factors 


\section{List of Figures}

\section{Chapter 2. Literature Survey}

Fig. 2-1.

Typical funnel and gate configuration

Fig. 2-2.

Trench and gate configuration

Fig. 2-3.

Site map

Fig. 2-4.

Plan view of stacked microbial degradation zones.

\section{Chapter 4. Remediation Site Database and Decision Trees}

Fig. 4-1.

Technology Decision Tool for Remediation of BTEX in low permeability soils.

Fig. 4-2.

Sample page from remediation site database. 


\section{Chapter 1. Introduction}

\subsection{Background Information and Problem Statement}

A large number of in situ remediation technologies and treatment trains have been investigated for the removal and destruction of organic contaminants in soil and groundwater. These techniques have been examined at the laboratory, pilot scale, and full-scale. In general, these technologies are either extractive or destructive. Extractive technologies remove contaminant mass (examples include in situ flushing and air-sparging) whereas destructive technologies destroy contaminant mass in situ (examples include chemical oxidation and bioremediation). Selected examples of technologies include in situ oxidation or reduction [1-3], bioremediation [4-12], natural attenuation [13-19], air-sparging [20-32], enhanced dissolution [33-37], and excavation. Many other technologies and approaches have been explored.

Because of the large number of technologies, the very different types of contaminants to which these technologies are applicable, and the wide range of field conditions, it can be difficult to choose an optimal technology for a specific site. Sorting and prioritizing the various factors which contribute to the success of a particular clean-up can be daunting. Furthermore, nontechnical factors, such as those in the legal, political, or financial realm, may also influence which technology is ultimately chosen.

Aromatic hydrocarbons, in particular benzene, pose a formidable clean-up challenge in part because the clean-up goal is so stringent. Most in situ treatment methods are effective in permeable soil. However, much of Indiana soil is low-permeability, so applicability of these methods is limited. For example, there are INDOT sites where contamination has migrated to spread over a large area of clayey soil. In one case, the contamination followed a building foundation. In some cases, very thin sand seams allow migration over time but do not allow the rapid movement needed for air-sparging or injection to be effective. Although soil fracturing is a possible technique for enhancing permeability and treatment effectiveness, fracturing would not be appropriate for many INDOT sites. Therefore, one of the few currently viable options is massive (and expensive) excavation and disposal.

\subsection{Research Scope and Approach}

The project is divided into six tasks. Task 1 consists of a literature review on remediation methods for low permeability soils. The Purdue University Library offers access to 171 on-line 
databases, spanning a tremendous range of topics and publication dates. Literature on remediation methods for low permeability soils were obtained through computer based search engines and data bases such as Compendex, The National Transportation Library (TRIS OnLine), Civil Engineering Abstracts, Environmental Engineering Abstracts, the Science Citation Index and many others. A more general search was conducted with various Internet search engines, to capture references that may not be found in traditional indices. The patent literature was also be explored, with particular emphasis on patents within the United States.

The second task consists of an assessment of INDOT sites and needs. Based on input from INDOT staff, selected site criteria were assessed for pollutant characteristics (concentration levels, type of pollutant) and geological and physical characteristics. This was necessary to determine the range of site conditions of interest to INDOT, and aided in the preparation of a decision tree that is relevant to INDOT needs.

The third task consisted of compiling information and assembling a searchable database (Microsoft Access) of remediated sites. Sites were chosen on the basis of their similarity to INDOT sites. Information regarding site conditions, contaminants, and remediation end-points were obtained and included in the database. Data was collected from federal agencies (for example, the U.S. EPA and the U.S. DOE). In addition, data was also collected from other state departments of transportation (DOTs) and state environmental protection agencies.

Task four is an analysis and evaluation of results. The PI and research assistant provided a critical review and summary of existing information and data. This type of literature review provides qualitative information, which is necessary for gaining a good overview of available technologies. The completed literature review was distributed to the SAC.

Preparation of the decision tree is the fifth task. Decision-tree analysis can be used to evaluate remediation strategies appropriate to INDOT sites. Decision-trees were produced based on the synthesis and analysis of literature data, and the assessment of INDOT sites. After review from the SAC, the decision-trees were combined into one single tree. The decision-tree was designed such that the user will answer a series of questions in order to determine whether or not to apply a certain remediation technology at the site. The questions were formulated by considering the remediation data obtained from the literature, and other information. Questions address physical and chemical characteristics of a specific pollutant, site characteristics and local conditions, and regulatory issues. 
A draft final and final report (task six) was prepared to summarize the literature survey and site assessments. The report contains detailed discussions of information retrieval methods, information sources, and analysis of the information. All facets of the decision tree are explained, including how it was constructed and the types of decisions to which it is applicable. In addition, the report comments upon implementation by INDOT and further research.

\subsection{Objectives and Purpose of the Study}

The purpose of the study is to develop decision-support tools for use by INDOT staff involved with site remediation. The decision-support tools include a remediation decision-tree for choosing technologies or combinations of technologies appropriate for specific types of sites, including sites with low-permeability soil. In order to develop a decision-tree, it is necessary to conduct a comprehensive analysis of remediation technologies, with a focus on investigations of aromatic hydrocarbons and low-permeability soils. Investigations at all spatial scales were considered. The analysis of the data and information include a descriptive component as well as a more quantitative aspect. The descriptive component aids in conveying a broad view of the remediation approaches and provides some context for users of the decision-tree.

The more quantitative analysis is the basis for constructing the decision tree and determining key decision points. Some of the considerations included in the decision tree are quantitative (for instance, the physical and chemical properties of the pollutant) and others are qualitative (e.g., do state regulations allow this category of remediation technology? Are there tanks present at the site?).

An additional objective is to construct a database of remediated sites in the region. The types of sites were screened so that they are as similar as possible to sites of interest to INDOT. In particular, information from sites that have been successfully remediated was chosen. This project expands the scientific basis for the development and application of innovative treatment for contaminated sites owned and operated by INDOT. Potential benefits include a more effective means of remediating benzene and other fuel hydrocarbons without having to excavate and dispose of contaminated soil. The use of a remediation decision tree may decrease the time needed to choose an effective technology. In addition to supporting decision makers at INDOT, the decision tree will benefit anyone who makes decisions about remediation at sites in Indiana and any other state with similar site characteristics. It is expected that the research findings developed during this project will be implemented promptly. 


\subsection{References}

1. $\quad$ EPA, Field Applications of In Situ Remediation Technologies: chemical oxidation. 1998: Washington DC.

2. $\quad$ ESTCP, E.T.S.C.P., Technology Status Review In Situ Oxidation. 1999.

3. Group, I.T.a.R.C.W. and I.S.C.O.W. Team, Technical and Regulatory Guidance for In Situ Chemical Oxidation of Contaminated Soil and Groundwater Technical/Regulatory Guidelines. 2001, Interstate Technology and Regulatory Council (ITRC): Washington DC.

4. Prenafeta-Boldu, F.X., et al., Bioremediation of BTEX hydrocarbons: Effect of soil inoculation with the toluene-growing fungus Cladophialophora sp. strain T1. Biodegradation, 2004. 15(1): p. 59-65.

5. Xu, Z., A. Mulchandani, and W. Chen, Detection of Benzene, Toluene, Ethyl Benzene, and Xylenes (BTEX) Using Toluene Dioxygenase-Peroxidase Coupling Reactions. Biotechnology Progress, 2003. 19(6): p. 1812-1815.

6. $\quad$ Prenafeta-Boldu, F.X., et al., Substrate interactions during the biodegradation of benzene, toluene, ethylbenzene, and xylene (BTEX) hydrocarbons by the fungus Cladophialophora sp. strain T1. Applied and Environmental Microbiology, 2002. 68(6): p. 2660-2665.

7. $\quad$ Beller, H.R., Analysis of benzylsuccinates in groundwater by liquid chromatography/tandem mass spectrometry and its use for monitoring in situ BTEX biodegradation. Environmental Science and Technology, 2002. 36(12): p. 2724-2728.

8. Montgomery, M.T., et al., Bacterial production stimulated across the zone of influence of a ground water circulation well in a BTEX-contaminated aquifer. Ground Water Monitoring and Remediation, 2002. 22(3): p. 144-150.

9. Schreiber, M.E. and J.M. Bahr, Nitrate-enhanced bioremediation of BTEX-contaminated groundwater: Parameter estimation from natural-gradient tracer experiments. Journal of Contaminant Hydrology, 2002. 55(1-2): p. 29-56.

10. Eckert, P. and C.A.J. Appelo, Hydrogeochemical modeling of enhanced benzene, toluene, ethylbenzene, xylene (BTEX) remediation with nitrate. Water Resources Research, 2002. 38(8): p. 51-511.

11. Cunningham, J.A., et al., Enhanced in situ bioremediation of BTEX-contaminated groundwater by combined injection of nitrate and sulfate. Environmental Science and Technology, 2001. 35(8): p. 1663-1670.

12. Durant, L.P.W., P.C. D'Adamo, and E.J. Bouwer, Aromatic hydrocarbon biodegradation with mixtures of $O<s u b>2</$ sub $>$ and $N O<s u b>3</$ sub $><$ sup $>-</$ sup $>$ as electron acceptors. Environmental Engineering Science, 1999. 16(6): p. 487-500.

13. Scheutz, C., H. Mosbaek, and P. Kjeldsen, Attenuation of Methane and Volatile Organic Compounds in Landfill Soil Covers. Journal of Environmental Quality, 2004. 33(1): p. 61-71.

14. Elsner, M., et al., Mechanisms and Products of Surface-Mediated Reductive Dehalogenation of Carbon Tetrachloride by Fe(II) on Goethite. Environmental Science and Technology, 2004. 38(7): p. 2058-2066.

15. Witt, M.E., et al., Natural attenuation of chlorinated solvents at Area 6, Dover Air Force Base: Groundwater biogeochemistry. Journal of Contaminant Hydrology, 2002. 57(1-2): p. 61-80. 
16. Rogers, S.W., et al., Natural attenuation of polycyclic aromatic hydrocarboncontaminated sites: Review. Practice Periodical of Hazardous, Toxic, and Radioactive Waste Management, 2002. 6(3): p. 141-155.

17. Borden, R.C., Natural bioattenuation of anaerobic hydrocarbons and chlorinated solvents in groundwater. Manuals and Reports on Engineering Practice, American Society of Civil Engineers, 2001(100): p. 121-151.

18. Azadpour-Keeley, A., et al., Monitored natural attenuation of contaminants in the subsurface: Processes. Ground Water Monitoring and Remediation, 2001. 21(2): p. 97107.

19. Yager, R.M., et al., Metabolic adaptation and in situ attenuation of chlorinated ethenes by naturally occurring microorganisms in a fractured dolomite aquifer near Niagara Falls, New York. Environmental Science and Technology, 1997. 31(11): p. 3138-3147.

20. Kim, H., et al., Surfactant-Enhanced Air Sparging in Saturated Sand. Environmental Science and Technology, 2004. 38(4): p. 1170-1175.

21. Rogers, S.W., K.-P. Chao, and S.K. Ong, Benzene nonaqueous phase liquids removal under air-sparged conditions. Journal of Environmental Engineering, 2004. 130(7): p. 751-758.

22. Adams, J.A. and K.R. Reddy, Extent of benzene biodegradation in saturated soil column during air sparging. Ground Water Monitoring and Remediation, 2003. 23(3): p. 85-94.

23. Reddy, K.R. and J.A. Adams, Effects of soil heterogeneity on airflow patterns and hydrocarbon removal during in situ air sparging. Journal of Geotechnical and Geoenvironmental Engineering, 2001. 127(3): p. 234-247.

24. Kirtland, B.C., C.M. Aelion, and M.A. Widdowson, Long-term AS/SVE for petroleum removal in low-permeability Piedmont saprolite. Journal of Environmental Engineering, 2001. 127(2): p. 134-144.

25. Murray, W.A., et al., Site 5 air sparging pilot test, Naval Air Station Cecil Field, Jacksonville, Florida. Journal of Hazardous Materials, 2000. 72(2-3): p. 121-145.

26. Rogers, S.W. and S.K. Ong, Influence of porous media, airflow rate, and air channel spacing on benzene NAPL removal during air sparging. Environmental Science and Technology, 2000. 34(5): p. 764-770.

27. Adams, J.A. and K.R. Reddy, Removal of dissolved-and free-phase benzene pools from ground water using in situ air sparging. Journal of Environmental Engineering, 2000. 126(8): p. 697-707.

28. Reddy, K.R. and J.A. Adams, Effect of groundwater flow on remediation of dissolvedphase VOC contamination using air sparging. Journal of Hazardous Materials, 2000. 72(2-3): p. 147-165.

29. Braida, W. and S.K. Ong, Influence of porous media and airflow rate on the fate of NAPLs under air sparging. Transport in Porous Media, 2000. 38(1-2): p. 29-42.

30. Johnston, C.D., et al., Volatilisation and biodegradation during air sparging of dissolved BTEX-contaminated groundwater. Journal of Contaminant Hydrology, 1998. 33(3-4): p. 377-404.

31. Johnston, C.D., et al., Volatilization and biodegradation during air sparging of a petroleum hydrocarbon-contaminated sand aquifer. IAHS Publication (International Association of Hydrological Sciences), 1998(250): p. 125-131. 
32. Wilson, D.J., et al., Groundwater cleanup by in-situ sparging. XIII. Random air channels for sparging of dissolved and nonaqueous phase volatiles. Separation Science and Technology, 1997. 32(18): p. 2969-2992. 


\section{Chapter 2. Literature Survey}

\subsection{Introduction and Purpose}

A large number of in situ remediation technologies and treatment trains have been investigated for the removal and destruction of organic contaminants in soil and groundwater. These techniques have been examined at the laboratory, pilot scale, and full-scale. In general, these technologies are either extractive or destructive. Extractive technologies remove contaminant mass (examples include in situ flushing and air-sparging) whereas destructive technologies destroy contaminant mass in situ (examples include chemical oxidation and bioremediation). Selected examples of technologies include in situ oxidation or reduction [1-3], bioremediation [4-12], natural attenuation [13-19], air sparging [20-32], enhanced dissolution [33-37], and excavation. Many other technologies and approaches have also been explored.

Because of the large number of technologies, the very different types of contaminants to which these technologies are applicable, and the wide range of field conditions, it can be difficult to choose an optimal technology for a specific site. Sorting and prioritizing the various factors which contribute to the success of a particular clean-up can be daunting. Furthermore, nontechnical factors, such as those in the legal, political, or financial realm, may also influence which technology is ultimately chosen.

Most in situ treatment methods are effective in permeable soil. However, much of Indiana soil is classified as "low-permeability," so applicability of these methods is limited Remediation of contaminants in low permeable media has challenged remediation engineers and scientists for several decades. In the past, expensive excavations were the only effective remediation strategies. Excavations costs range from $\$ 270$ to $\$ 460$ per ton depending on site 
characteristics and excavation methods. These cost estimates include contaminant removal, transportation and disposal at a RCRA permitted facility [38].

The purpose of this literature survey is to aid the Indiana Department of Transportation (INDOT) with decision making tools for the remediation of aromatic hydrocarbons in lowpermeability soil. Since a large portion of Indiana's immediate subsurface consists of clay and glacial till, INDOT has a number of sites requiring remediation in this media. Because aromatic hydrocarbons are of interest to INDOT, gasoline, diesel, kerosene, and waste oil are contaminants of particular interest, and the focus of literature review.

\subsection{Subsurface of Indiana}

Soils vary significantly throughout Indiana and are a direct result of recent glaciations. A majority of the state's soils parent materials are glacial till. As a result the hydraulic conductivity of these soils is low. Since most areas are covered by loess, the topsoil in many areas of northern and central Indiana is excellent for growing crops. One must go deeper into the subsurface to encounter low permeability tills (typically less than $10 \mathrm{ft}$ ). Exceptions to the areas with low permeability are regions along major rivers and areas near Lake Michigan. Alluvial and outwash deposits prevail near the rivers and eolian sand prevails near the lake. As a result the permeability is high. The most recent glaciation did not reach south of Morgan County. Therefore the soils are older and most are loess deposits over weathered limestone, sandstone or shale. Based on the parent material, the resulting soil will reflect the parent materials properties. A map of the various soil regions of Indiana can be found in the Indiana Soil and Landscape Evaluation Manual (reference 61 in Chapter 2).

\subsection{Contaminant Removal}


Removal of contaminants is hindered in soils with low hydraulic conductivity $\left(10^{-5} \mathrm{~cm} / \mathrm{s}\right.$ or less) due to two main factors. The first factor is that pathways to remove the contaminants are not as abundant as in permeable soils. Since most in situ technologies require sufficient pathways for contaminant remediation, this poses a problem. The second factor is that the primary transport processes are governed by diffusion. These transport times are much greater than advective flow and as a result groundwater flow is very slow. For example, if the contaminants benzene, toluene, ethyl benzene, and xylene (BTEX) remain in an aquifer for one year and the contaminants diffuse into the clay, then it would take ten years for $85 \%$ the total mass to diffuse out of the clay if the proper pathways are present [39]. Advective processes would then carry the contaminated groundwater for treatment. Contaminants are "sequestered" in the interior pores of the soil, which increases with time [40].

\subsection{Decision Making}

Successful decision making in environmental remediation depends on three components; people, processes, and tools. The typical combination of people involved includes decision makers, scientists and engineers, and the general public. It is the goal of each group to provide as much information as possible so that each group, and in the end the decision makers, can make educated decisions. Joint considerations need to be considered of the environmental, ecological, technological, economic, and sociopolitical factors relevant to the remedial design. As to date, multicriteria decision analysis (MCDA) is an academic tool that can be applied to real world scenarios. Recently developed software such as Expert Choice (www.expertchoice.com), Criterim Decision Plus (www.infoharvest.com), and Decision Lab (www.visualdecision.com) provide more information on how MCDA can be applied to specific sites [41].

\subsection{Technologies}


An overview of the technologies discussed in Section 2.5 is show below, in Table 2-1.

\subsubsection{Thermal Technologies}

\subsection{1.a. Technical Basis and Overview}

Thermal technologies show promise in low permeability soils. Thermal technologies increase in situ removal of volatile compounds by increasing the vapor pressure and evaporation rates. Increasing the temperature decreases interfacial tension between light non-aqueous phase liquids (LNAPL) and water, increases water wettability and also increases desorption of contaminants. Once the contaminant is desorbed, pathways are needed for removal. Therefore a combination of increasing the permeability and thermal techniques is necessary. The more standard techniques of steam, heated air and hot water require sufficient flow paths for increased volatization of aromatic hydrocarbons. However electrical resistance (ER) and radio frequency (RF) heating do not. Because ER \& RF do not require flow paths, they are more applicable in low permeability soils. However soil vapor extraction (SVE) to remove vapors must have sufficient permeability [42]. Extensive field tests and pilot tests need to be done before its use is applicable in the field. As of today the use of thermal technologies is not economical.

\subsection{1.b. Case Studies and Examples}

Electrical Resistance Heating (ERH) and Multi-Phase Extraction (MPE) were used successfully to remediate a hydrocarbon plume in a sandy clay saprolite with moderately low permeability and high heterogeneity. The hydrocarbon was a specialty fuel similar to kerosene or diesel fuel. The hydrocarbon covered an area of $4900 \mathrm{ft}^{2}\left(500 \mathrm{~m}^{2}\right)$ and was up to $10 \mathrm{ft}(3 \mathrm{~m})$ thick, with most wells containing 1-3 ft (0.5-1 m) of hydrocarbon. The static water table was approximately $24 \mathrm{ft}$ (7 m) below grade. [43]

A combination of 50 extraction/monitoring wells and ERH electrodes were installed. 
The electrodes directed electrical heating into the region from 20 to $30 \mathrm{ft}$ (6 to $9 \mathrm{~m}$ ) below grade. The wells extracted hydrocarbon and vapors from 22 to $27 \mathrm{ft}$ (6.5 to $8.5 \mathrm{~m})$ below grade. A positive displacement vacuum blower was used to apply a vacuum to the subsurface. On average 11 inches of mercury vacuum was applied to the extraction wells, which resulted in a vapor extraction rate of about $12 \mathrm{scfm}\left(20 \mathrm{~m}^{3} / \mathrm{hr}\right)$ per well and a liquid extraction rate of $0.25 \mathrm{gpm}(1$ L/min) per well. Vapor and steam flow from the wells passed through a steam condenser to cool the vapor and remove steam. A thermal oxidizer was used to destroy emissions before they reached the atmosphere. [43]

Remediation began on May 27, 1999; by December 10, 1999 hydrocarbon levels were reduced to $1 / 8$ inches $(4 \mathrm{~mm})$. Several mechanisms were used to remediate this site: heating to reduce hydrocarbon NAPL viscosity, steam bubble flotation and hydrocarbon agitation by rising steam bubbles, thermally enhanced vaporization (fuel boiling) and vacuum-enhanced pumping [43].

\subsubsection{Trench and Gate Systems}

\subsection{2.a. Technical Basis and Overview}

The funnel and gate remedial system is a passive system designed to treat contaminated groundwater as it passes through a treatment gate (see Fig. 2-1). The funnel directs the groundwater through a treatment gate, which is often a permeable reactive barrier (PRB). The PRB consist of a wide array of solid media, including zero valent iron and activated carbon. The contaminant can be destroyed (e.g., chemical reaction within the barrier) or removed (adsorbed onto the media). For BTEX it is possible to apply a reactive "zone" with air-sparging. A major limitation to the funnel and gate system is that in low permeability soils, groundwater flow is 
extremely slow and therefore passive treatment through a PRB would require a long time, on the order of decades.

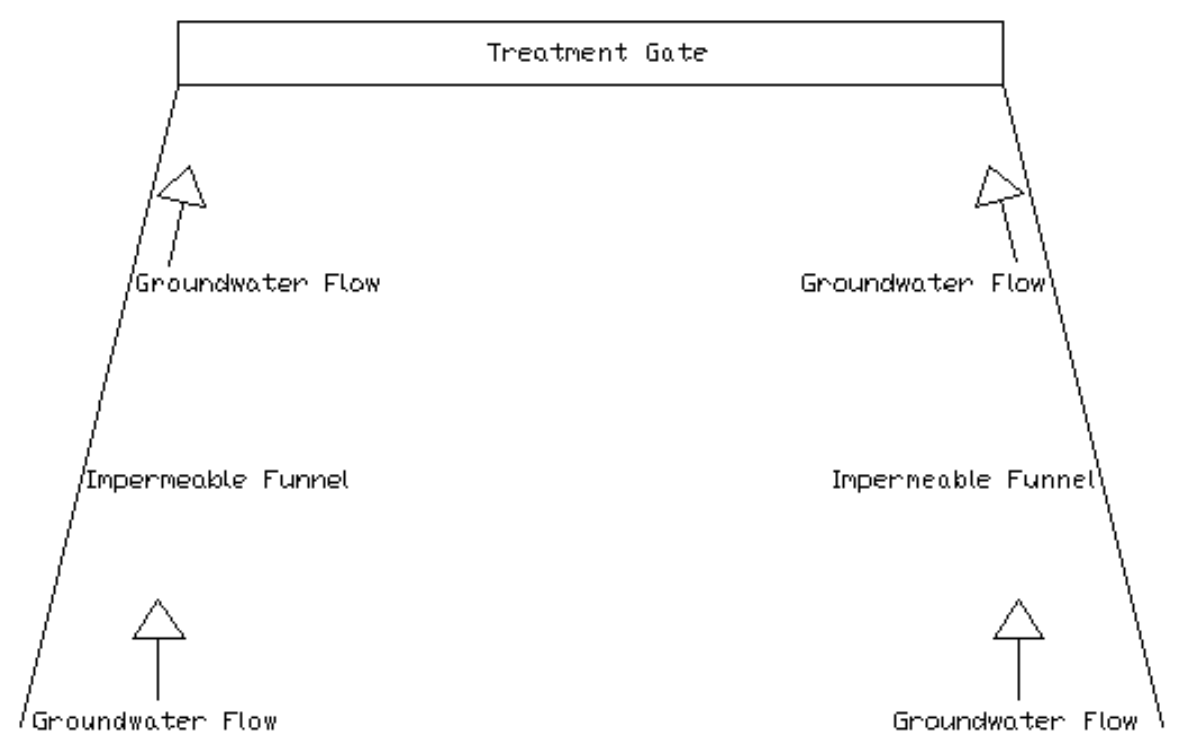

Figure 2-1. Typical Funnel and Gate Configuration

Certain modifications can enhance the performance of a funnel and gate system in low permeability soils. For example, the trench and gate system includes the addition of high hydraulic conductivity “drainage trenches” along the up gradient side of the funnel walls and a discharge re-infiltration gallery down gradient from the treatment gate (see Fig. 2-2). The drainage trenches consist of high permeable materials laid on the up-gradient edge of the impermeable funnel, focusing the contaminated water into media of higher hydraulic conductivity for treatment. 


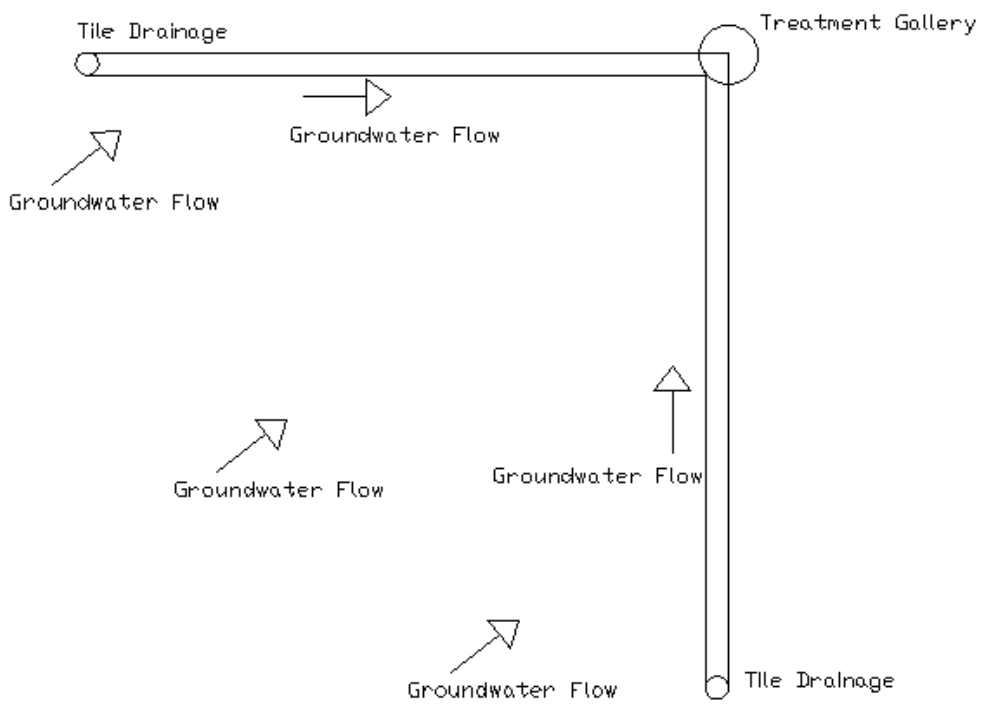

Figure 2-2. Trench and Gate Configuration

\subsection{2.b. Case Studies and Examples}

At the East Garrington Study Site, L-shaped monitoring wells were constructed in an L shape with a long foot extending down the trench. The wells were for monitoring and also served as conduits for injecting remediation or other fluids. However after four years, it was not necessary to use them for any type of injection. Under the $\mathrm{L}$ shaped wells and permeable media is a $0.25 \mathrm{~m}$ diameter, slotted PVC pipe that drains directly into the first gate, similar to tile drainage. The gates are constructed of three $1.8 \mathrm{~m}$ diameter by $6 \mathrm{~m}$ high cylindrical galvanized culverts set vertically into a cement foundation. They are connected to the tile drainage in the trench arms, each other, and the re-infiltration gallery. Shut off valves are located through the system to allow for repair work. The first gate holds the micro-pore hose for bioremediation. It is attached to a galvanized base on the floor. [44]

Since the concentrations of the contaminants of concern (BTEX) on-site vary from nondetectable to $10 \mathrm{mg} / \mathrm{L}$ they were treated via biosparging (low flow, small bubbles) in the first gate. Biodegradation becomes the main mechanism for BTEX removal at low concentrations. 
Dissolved oxygen (DO) concentrations in contaminated groundwater are typically $0.5 \mathrm{mg} / \mathrm{L}$ or less due to consumption of DO by microbes. By biosparging, levels can be brought up to 6 to 10 $\mathrm{mg} / \mathrm{L}$ under equilibrium concentrations, thereby providing DO for microbes involved in BTEX consumption [45]. After remediation, BTEX limits were reduced to below the detection level of $0.001 \mathrm{mg} / \mathrm{L}$. In rare cases where levels were detected, they were so low that natural attenuation (biodegradation) is believed to remove the remainder in the near future. [44]

Advantages of the trench and gate system include prevention of off-site migration of pollutants. It can be used to isolate "trouble areas" subject to multiple contaminant releases (examples: tank farm, fueling station), reducing the need for and cost of repetitive clean-ups. The system can be tailored to treat a variety of contaminants. The open gate configuration allows for routine maintenance. Modifying the inlet for a two gate system to allow for water table entry may also allow for a LNAPL separator. As a cost saving measure, the use of only one gate would decrease the initial construction cost. The addition of a pump on the downgradient end of the gate and re-injecting remediated groundwater up-gradient will flush the contaminated area and could speed up remediation. [44]

There is a significant initial investment; however once installed the system requires minimal maintenance and is much less expensive than pump and treat. The trench and gate system offers a variable, long term remediation system capable of treating groundwater plumes in low to moderate hydraulic conductivities. It can be applied to many sites.

\subsubsection{Bioslurping}

\subsection{3.a. Technical Basis and Overview}

Bioslurping technologies are being developed for the cleanup of LNAPL at sites that have free product contamination. Vacuum-enhanced extraction/recovery systems are used to 
remove free phase LNAPLs from the water table. Vapor extraction is used to remove vapors from the vadose zone. The main components consist of recovery wells with slurp tubes, vacuum pump(s) to extract liquids and vapors (liquid ring pump), liquid/vapor and oil/water separation units, and water - vapor treatment units.

The process begins by installing an unslotted "spear" or "slurp tube” of adjustable length into the recovery well extending into the LNAPL layer. A vacuum is applied which extracts free product, groundwater, and soil gas. The system cycles between removing liquids (product and groundwater) and vapors through the slurp tube. An additional benefit of removing vapors is the aeration of the unsaturated zone which increases the rate of aerobic biodegradation [46].

If the pumping rate is sufficiently high, and the depth to the water table is within 25 feet, product will flow up the tube as a solid column. Otherwise it can be extracted as slugs or film, or "slurped" upward via entrainment [47].

\subsection{3.b. Case Studies and Examples}

Similar to bioslurping, the FIVE System is an acronym for Fluid Injection and Vacuum Extraction. Bechtel National, Incorporated, and OHM Remediation Services Corporation developed the patented system for use at the Naval Air Facility in El Centro, California. On site hydrocarbon levels in the soil were up to $600,000 \mathrm{mg} / \mathrm{L}$ (saturated) and groundwater up to $910,000 \mathrm{mg} / \mathrm{L}$ (free product). The remediation goal was to remediate the site to regulatory levels in one year. [48]

Remediation involved multiphase extraction, pneumatic soil fracturing, vacuum extraction, and bioremediation. The same principles as dual phase extraction combined with pneumatic soil fracturing to remove hydrocarbons and enhance bioremediation were applied. Extraction wells used vacuum and water entrainment to remove contaminated groundwater, free 
product, and vapors. After pilot tests confirmed that the system would be effective, full-scale remediation began. One hundred and twenty-two $10 \mathrm{~cm}$ diameter extraction wells, screened from 2-5 m were installed. One $115 \mathrm{~m}$ long horizontal vapor extraction well, with $60 \mathrm{~m}$ long screen, $3 \mathrm{~m}$ below grade was also installed (see Fig. 4). Both liquids and vapors were extracted with a flexible $5 \mathrm{~cm}$ diameter hose (slurp tube), placed at the bottom of the extraction wells. [48]

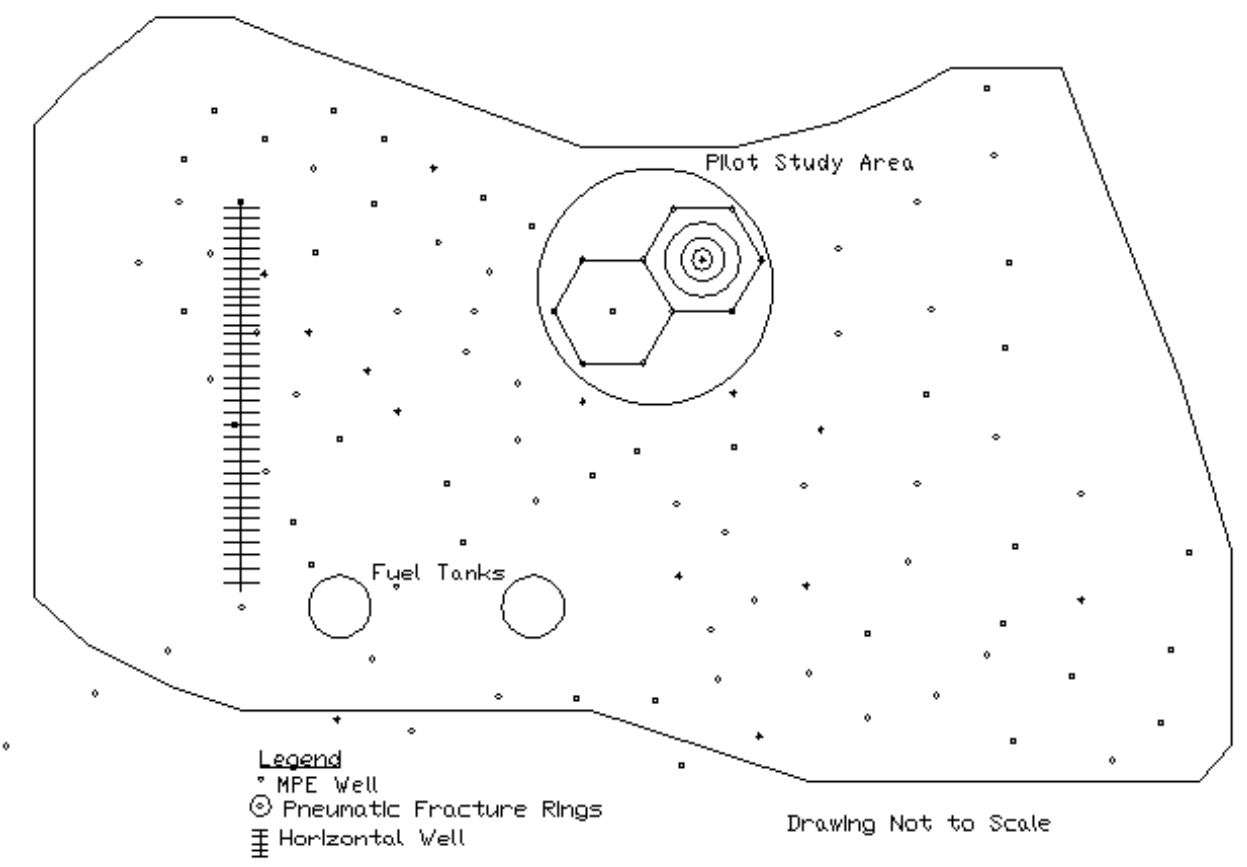

Figure 2-3. Site Map

A total of 300 pneumatic fracture points were installed. It was discovered that approximately $140 \mathrm{kPa}(20 \mathrm{psi})$ was required to achieve $2.3 \mathrm{~L} / \mathrm{min}(5 \mathrm{scfm})$ flow rate to achieve fracturing in the clay. The purpose of the placement of the wells between extraction wells was to increase well spacing, further increase horizontal permeability, and to increase the amount of oxygen available for aerobic biodegradation. Fracturing was essential to create pathways in the clay, through which volatiles migrated, and to distribute oxygen. [48]

The groundwater on site was lowered by the extraction wells, which exposed the clay, resulting in desiccation and further opening of pre-existing fractures. These processes increased 
mobilization of free product and vadose zone permeability. Also, by lowering the water table, hydrocarbons in the smear zone were exposed, permitting vapor extraction wells to remove the volatiles. Soil moisture, initially at $100 \%$ was reduced to $25 \%$ during operations. [48]

After the free product and volatiles were removed, bioremediation became the primary mechanism for remediation. Soil and groundwater were acceptable for microbial growth with a $\mathrm{pH}$ ranging between 6 and 8 , temperatures above $16^{\circ} \mathrm{C}$, and aerobic groundwater with dissolved oxygen content from 0.86 - $5.85 \mathrm{mg} / \mathrm{L}$ [48].

\subsubsection{Surfactants}

\subsection{4.a. Technical Basis and Overview}

Chemicals that accumulate at the water surface and reduce the air-water interfacial tension are considered surfactants. By reducing the air-water interfacial tension an additional transport barrier is created. The hydrodynamics of the water surface are changed so that the transport of solutes by eddies approaching the water surface is reduced (hydrodynamic damping) [49].

Surfactants are unable to remove contaminants from inaccessible areas (low hydraulic conductivity). Vertical flushing can be applied to vadose zone contaminants where the vertical conductivity is sufficient. Surfactant are injected into vertical injection wells and then collected down gradient. Horizontal flushing can be used in the saturated zone, under buildings, and possibly in horizontally stratified, low permeability soils [50]. It has been hypothesized that in naturally fractured low permeability soils, dissolution would remove residual product adhering to fractures sides. The time for remediation would be based on diffusive transport and would be on the order of years in most circumstances [50]. 
With pooled LNAPL, depressing the water table and pumping out product is a conventional technique that can be improved by surfactant flushing. When the majority of the contaminant is removed, less aggressive strategies like bioremediation can be used [50].

In stratified low permeability soils (no field data) limitations are based on how low the hydraulic conductivity is, and surfactant access issues. Contaminant recovery in isolated lenses would be slower than recovery in continuous lenses. Removal would be through diffusion; for a $1 \mathrm{~cm}$ lens it would take longer than a year (diffusion to permeable layer + advective transport time in permeable strata). In massive clays, where contaminants have diffused into clay blocks, surfactant flushing would be ineffective unless the permeability was increased [50].

2.5.4.b. Case Studies and Examples

A combination of surfactants and electrokinetic methods in low permeability soils is feasible and an example will be discussed in Section 2.4.5.b.

\subsubsection{Electrokinetic Methods}

\subsection{5.a. Technical Basis and Overview}

Electrokinetic remediation is an emerging technology that has been studied in the laboratory. The process involves the installation of electrodes into wells and the application of a low-electric potential across the anode and the cathode. By inducing an electrical potential, a number of physicochemical process including electro-osmosis occur. Electro-osmosis can transport a solution through clayey soils much faster than the unaltered hydraulic gradient [51]. The technology is applicable to metals and soluble organics (including PAHs) in fine-grained soils. A more recent development involves reversing the polarity of the electric fields to pass

contaminants repeatedly through a degradation zone. This process is known as the "Lasagna" process. 
In one recent report, the investigators studied cyclodextrin-enhanced electrokinetic removal of phenanthrene from kaolinite in the laboratory [52]. They found that the pore solution $\mathrm{pH}$ near the anode was acidic $(\mathrm{pH} \sim 2)$ and near the cathode basic $(\mathrm{pH} \sim 12)$. Advantages over pump and treat include control over flow direction and that the system works in low-permeability soils. However it may be necessary to increase mobility of hydrophobic organic contaminants (HOCs) for EK to be effective [52].

\subsection{5.b. Case Study and Examples}

Electrokinetic remediation using surfactants and cosolvents has been studied in the laboratory. Phenanthrene (a PAH) was used as the test contaminant. The investigators found that PAH sorption predominates in soils with large amounts of organic matter and/or clay/silt sized particles, due to their large surface areas as well as electrical charges [53]. Closer to the cathode the chemistry of the soil and solution changes causing the contaminants to become trapped on the soil particles. Removal rates for test columns ranged from $25 \%$ to $56 \%$ and the results confirm that hydroxypropyl- $\beta$ - cyclodextrin (HPCD) enhances phenanthrene desorption from kaolinite. Further research is necessary, although results are promising [53].

\subsubsection{Fracturing}

\subsection{6.a. Technical Basis and Overview}

Fracturing improves the formation's porosity and thus improves the performance of other in situ technologies. If the permeability of the formation is increased, contaminant transport can be achieved by both diffusion and advection, which leads to a shorter time needed for contaminant removal. 
Pneumatic fracturing is completed by the injection of high pressure air into the formation. A proprietary device known as a "HQ Injector" exists that applies pressurized air along discrete two-foot intervals. It can be repositioned at various depths to create a fractured network [54].

Hydraulic fracturing is completed by the injection of high pressure water through a sealed borehole. The process is completed by using a slurry of coarse sand and guar gum gel to fill the fractures. An enzyme breaks down the slurry and after it is pumped out a permeable channel (filled with sand) is left. Pneumatic fracturing is cheaper and easier than hydraulic; however the fractures can close, which results in a need for additional fracturing. Hydraulic fracturing is more expensive and complex than pneumatic fracturing; after the process is completed dewatering may be necessary. However the fractures are filled with sand, and are unlikely to reclose [55].

Fractures increase permeability and exposed surface area and decrease the path length for contaminant transport to removal points, therefore reducing the number of extraction wells needed. Pneumatic fracturing is a quick process, with the duration of the injection of 10-20 s. On average, a fracturing injection cycle can be completed in 30 minutes. Ten to fifteen fractures can be created by a three person crew in an eight hour day [56]. Fracturing by itself can not remove or destroy contaminants but it is technique that can increase permeability, thereby allowing other technologies to work more efficiently.

\subsection{6.b. Case Study or Examples}

A combination of pneumatic fracturing and SVE was investigated in a pilot study at a facility of the Xerox Corporation in Oak Brook, Illinois. Although the site was contaminated with TCE and other chlorinated VOCs, and not aromatic hydrocarbons, the approach used at this site is applicable to sites with aromatic hydrocarbons. Sampling revealed that the soil was 
contaminated with TCE and other chlorinated VOCs ranging up to $150,000 \mu \mathrm{g} / \mathrm{kg}$ of total halogen content and extended to a depth of $6 \mathrm{~m}$ below grade. The site occupies 4 acres and the lithology consists of clayey glacial drift interbedded with lenticular sand deposits. The drift is approximately $12 \mathrm{~m}$ thick and can be divided into an upper weathered zone that extends to 3.7 $4.3 \mathrm{~m}$ below grade and a lower unweathered zone. The water table was on average $9 \mathrm{~m}$ below grade. The permeability of the glacial drift ranged from $4 \times 10^{-6}$ to $7 \times 10^{-7} \mathrm{~cm} / \mathrm{s}$.

A total of six hydraulic fractures were created in two separate boreholes at depths of approximately 1.8, 3.0 and $4.6 \mathrm{~m}$ below grade. By comparing pre-fracture data with postfracture data, it was determined that the air flow rate increased from $400-700 \%$, and averaged $600 \%$. On average TCE concentrations increased from 50 to $58 \mathrm{ppmv}$ after fracturing and lead to a mass removal rate increase of $675 \%$. Also a more complex gas mixture of higher concentrations of benzene, chloroform, and tetrachloroethane were present after fracturing. Fracturing is thought to have improved the connections of pockets of gas [55].

Another example is a gasoline station site that was contaminated by petroleum hydrocarbons from leaking underground storage tanks (USTs). BTEX levels exceeded 16,026 $\mu \mathrm{g} / \mathrm{kg}$ on 4 out of 11 soil borings to a depth of $3.6 \mathrm{~m}$. The subsurface consists of $40 \mathrm{~m}$ of gray clayey and silty clay till. [55]

Hydraulic fractures were formed in the contaminated area using two bore holes that were later used as SVE wells. The fractures were installed at depths of 2, 2.75 and $3.6 \mathrm{~m}$. Two additional wells were also installed to compare the performance of fractured and conventional wells. During SVE testing contaminant vapor recovery was not possible because of the presence of water in the soil pore space. The fractured wells continued to produce water throughout the study period where water recovery diminished after several days at conventional 
wells. This suggests that fractured wells influenced a greater area and improved liquid flow through the soil. [55]

The Denver Federal Center in Denver, Colorado was remediated using a combination of hydraulic fracturing and an inoculum of indigenous microbes. The subsurface consists of tightly-packed clay and shale which was contaminated by cutting oil used in the production of munitions. At the end of the 9-month demonstration total petroleum concentration (TPH) fell by an average of 91.5 percent. [57]

Initially horizontal fractures were created at the base of pre-drilled wells using high pressure water at various depths. Then an aqueous guar gum slurry carrying small ceramic pellets consisting of diatomaceous earth (isolite) extended and filled the fractures. The porous pellets were saturated with a liquid inoculum of indigenous microbes capable of degrading petroleum hydrocarbons. By using this method, isolite transports microbes into soil and groundwater while maintaining the permeability of fractures, thereby creating a permeable reactive treatment system that degrades contaminants. Perched groundwater was present in the clay which led to the treatment of both soil and groundwater. The fractures increase the soils permeability and the contaminated groundwater flowed through the fractures and was degraded by the introduced microbes. [57]

Based on the demonstrations results which were released in 1996, EPA Region 8 and the State of Colorado have used similar techniques at two underground storage tank sites in Colorado. Preliminary data showed that one site showed reductions in benzene concentrations of 80 percent and a total BTEX reduction of 85 percent. [57]

\subsubsection{Soil Vapor Extraction}

\subsection{7.a. Technical Basis and Overview}


Air sparging and soil vapor extraction (SVE) are the most common remedial technologies for BTEX remediation in homogeneous moderate to high permeability soils. For SVE to be successful in tight soils, the permeability will have to be increased. Threshold permeability for SVE is about $10^{-8} \mathrm{~cm}^{2}$ or $100-1000 \mathrm{scfm}$ [24]. SVE alone is not an effective technology for remediation in low permeability soils. However the combination of SVE and fracturing is a feasible combination of techniques. An example is described in section 2.4.6.b.

\subsubsection{Bioremediation}

\subsection{8.a. Technical Basis and Overview}

In situ bioremediation is considered to be one of the most cost-effective technologies for the treatment of BTX-contaminated soils [54]. For in situ bioremediation to be cost-effective and time-efficient, the degradation of contaminants often needs to be stimulated by the introduction of nutrients, oxygen sources, or alternate electron acceptors into the contaminated media.

In low permeable soils this introduction of stimulates is not possible due to transport limitations. Therefore the use of in-situ bioremediation as the sole technique in low permeability soils is not feasible. Combining fracturing techniques allow for the introduction of microbial amendments. Within a fractured network there will be zones of unfractured soil. The distance between the zones will depend on the frequency of fractures and the sites geology. A "stacked" system or gradient of microbial degradation will develop based on the availability of oxygen and nutrients. With the area closest to the fracture degrading via aerobic processes, the second stack as anaerobic denitrifying and the bottom stack as anaerobic methanogenic. [54] 


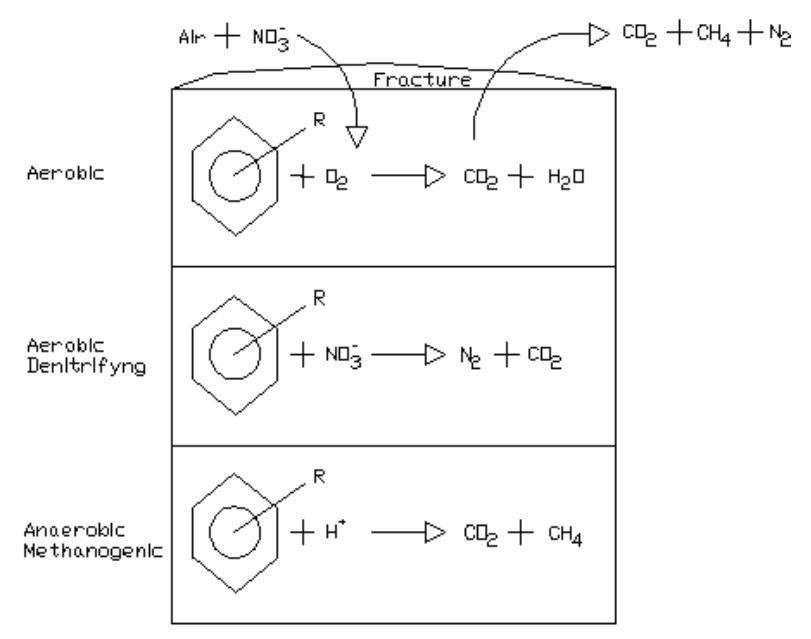

Figure 2-4. Plan View

\subsection{8.b. Case Study or Examples}

A pilot-scale study was completed to evaluate the integration of pneumatic fracturing and bioremediation at a Delaware Valley refinery. The study lasted 24 months and removed BTX from low permeability soils. The process was completed in various steps. The first step was to pneumatically fracture the formation using the HQ injector. After the subsurface is initially fractured with air the next step is to supply the subsurface with nutrients and other amendments to stimulate biological activity. Liquid amendments are supplied through the main injection air stream through the already fractured formation. By maintaining a high air-to-liquid ratio, the liquid supplements are atomized and are able to penetrate the formation more effectively. Additional amendment injections are made to replenish the nutrients and electron acceptors and to enhance aeration. [54]

The final step was to operate the site as an in situ bioremediation cell. Continuous air flow was maintained through the formation by using a vacuum pump at a central extraction well. Outlying wells were vented to allow for passive air inflow into the formation. Air flow was 
limited and maintained at a low flow to minimize air stripping and to maximize in situ biodegradation. [54]

After a year of sampling and monitoring, soil samples from the site showed a large reduction in soil-phase BTX concentrations. The total mass of BTX removed was computed to be $22 \mathrm{~kg}$ or $79 \%$ of which $85 \%$ was attributed to be removed via biodegradation. [54]

\subsubsection{Barometric Pumping}

\subsection{9.a. Technical Basis and Overview}

Barometric pumping or enhanced natural venting is a technology that is currently being developed to aid in the remedial process at sites with near surface VOC contamination in the vadose zone. The process is an in situ containment and extraction methodology. The process works on the cyclic movement experienced by soil gas due to oscillations in atmospheric pressure [58]. Daily variations in pressure are typically 5 millibars while passing weather fronts produce changes of 25 to 50 millibars. The changes in pressure can cause bulk vertical movement in the soil gas from millimeters to meters. The amount of movement depends on the amplitude of the pressure oscillations, soil gas permeability, and depth to an impermeable boundary such as the saturated zone.

To allow for the upward movement of vapors and to avoid the downward movement of vapors, surface features are installed. The system incorporates a surface seal, a plenum, and an extraction vent valve. Directly above the contaminant plume a high permeable material is installed to form a collection plenum to collect the upward migrating vapors. During time when there is high pressure the surface valve is shut. When there is relatively low pressure the soil gas rises and the valve opens and releases the vapors to the atmosphere. Since the migration of soil 
gas is slow, the release of VOCs from the vadose zone to the atmosphere should be low enough that natural ozone will destroy the contaminants below regulatory release levels.

The system can work in the latter phases of remediation or when a site has already been actively remediated and residual contamination exists. Below grade usage of the site is not possible in the plume area; however the above grade usage of the site as a parking lot could also be used as a surface seal. Underground storage tanks, leaking pipelines, and surface spills are applications where the system is feasible.

Transport limitations in both the saturated and unsaturated zone are responsible for the relatively small concentration gradient that drives mass transfer from groundwater to soil gas. However, the large air-water interfacial tension area of many BTEX contaminated aquifers and their high Henry’s law constants may lead to significant contaminant mass loss [59].

Once the system is installed there is minimal site disturbance and electricity is not needed on site to run any equipment. The design cost of barometric pumping alone is estimated to be less than $\$ 30 \mathrm{~K}$ per installation since no boreholes or active off-gas systems are not necessary [58]. Barometric pumping is not yet a proven technology and limitations may be encountered in low permeability soils. The addition of pneumatic fracturing will raise the cost, but enhance the feasible in low permeable subsurface.

\subsection{Sources and Quality of Literature Data}

Numerous journals, patents and other literature have been examined. The literature was located by searching Internet based search engines (e.g., Google Scholar, Yahoo) and databases such as Compendex, The National Transportation Library (TRIS On-Line), GeoRef, Pollution Abstracts, Science Online, Water Resources, Web of Science Proceedings, Environmental 
Engineering Abstracts, Civil Engineering Abstracts, Engineering Research Database, and the Science Citation Index. United States patents were also searched and reviewed.

The quality of the journal articles was assessed by evaluating the journal impact factor for the journal in which the article appeared. Journal impact factors and other information were obtained from Journal Citation Reports (JCR), a resource that allows users to evaluate and compare journals. Data is based upon 7,000 scholarly and technical journals from more than 3,300 publishers and indicate the most frequently cited journals, highest impact journals, and the most published articles in a field [60]. Journals with the highest impact and those most frequently cited tend to be better sources for information that those journals with low impact factors and low citations. The journal impact factor is roughly correlated with journal quality; the higher the number, the higher "quality" the journal. However, the journal impact factor is not the only measure of journal or article quality. The journal impact factors for journals cited in this literature survey are shown in Table 2-2. Note that impact factors are not available for other data sources (e.g, patents, technical reports).

\subsection{Conclusion}

Upon investigating remediation of aromatic hydrocarbons in low permeability soils many remedial technologies and combinations of technologies were evaluated. Electrokinetic methods were developed with the goal of remediation in low permeability soils. The technology shows promise, but it not yet proven in the field. The use of surfactants in combination with electrokinetic methods shows promise in the future.

Thermal techniques are limited by the physical removal of contaminants once they are desorbed from soil. As shown in the previous case study (section 2.4.1.b), remediation was completed via extraction wells in a sandy clay saprolite with moderately low permeability. If the 
soil had been any less permeable, remediation via extraction wells would have been hindered. Fracturing the subsurface will make the removal of contaminants more feasible with thermal technologies in low permeability soils.

The Trench and Gate System can be used for remediation of hydrocarbons in low permeability soils. Advantages to the system include the prevention of off-site migration. Since the system is passive, the time for remediation is depended on the time it takes for contaminated groundwater to pass through the treatment gallery. Groundwater flow is accelerated by trenching, but in general this system requires time for it to work.

The FIVE System is an integrated approach which combines multiphase extraction, pneumatic soil fracturing, vacuum extraction, and bioremediation to remediate high levels of organic contaminants in a relatively short period of time. Bioremediation is the method for removal of the lower concentrations or lingering contaminants.

Remediation challenges in low permeability soils can be overcome by an integrated approach. Based on contaminant levels, depth to groundwater, microbiological activity and other factors remediation can be achieved economically at many sites. As time progresses many of the technologies will become proven in the field and the task of choosing which remedial technology to apply in low permeability soils will be less of a challenge. Until the technologies become more developed, conventional excavation methods will be the best choice to remediate source areas. Most of the technologies discussed in this document are more applicable for the remediation of non-source plumes. 
Tables

Table 2-1: Overview of Technologies

\begin{tabular}{|c|c|c|c|c|}
\hline Technology & Application & $\begin{array}{l}\text { Estimated Cost } \\
\left(\$ / \mathrm{yd}^{3}\right)\end{array}$ & $\begin{array}{l}\text { Rapid } \\
\text { Closure } \\
\text { Possible? }\end{array}$ & $\begin{array}{l}\text { Proven } \\
\text { Technology? }\end{array}$ \\
\hline $\begin{array}{l}\text { Electrical } \\
\text { Resistance Heating }\end{array}$ & $\begin{array}{l}\text { Heavily } \\
\text { contaminated } \\
\text { groundwater } \\
\text { remediation. }\end{array}$ & $\begin{array}{l}\text { Laboratory test only, no field } \\
\text { applications. }\end{array}$ & Yes & Yes \\
\hline Trench and Gate & $\begin{array}{l}\text { Groundwater } \\
\text { remediation }\end{array}$ & No data. & No & Yes \\
\hline Bioslurping & $\begin{array}{l}\text { Heavily } \\
\text { contaminated } \\
\text { groundwater } \\
\text { remediation. }\end{array}$ & $\begin{array}{l}\text { Design and installation } 80 \mathrm{~K}, 40 \mathrm{~K} \\
\text { per year operating expenses. } \\
3,900 \mathrm{~L} \text { of LNAPL recovered per } \\
\text { year or avg. recovery of } 3.51 \mathrm{~L} \\
\text { per hour [46]. }\end{array}$ & Yes & Yes \\
\hline Electokinetic & $\begin{array}{l}\text { Groundwater } \\
\text { remediation. }\end{array}$ & $20-225$ & No & No \\
\hline $\begin{array}{l}\text { SVE \& Pneumatic } \\
\text { Fracturing }\end{array}$ & $\begin{array}{l}\text { Vadose zone } \\
\text { remediation. }\end{array}$ & 31 [39] & Yes & Yes \\
\hline $\begin{array}{l}\text { Bioremediation \& } \\
\text { Pneumatic } \\
\text { Fracturing }\end{array}$ & $\begin{array}{l}\text { Vadose zone } \\
\text { remediation. }\end{array}$ & $\begin{array}{l}\text { Pneumatic Fracturing alone is } 7 \text {. } \\
\text { [39] Combination may be } 10-20 \text {. }\end{array}$ & No & Yes \\
\hline $\begin{array}{l}\text { Barometric } \\
\text { Pumping }\end{array}$ & $\begin{array}{l}\text { Vadose zone } \\
\text { remediation. }\end{array}$ & Minimal & No & No \\
\hline Excavation & $\begin{array}{l}\text { Vadose and } \\
\text { saturated zone } \\
\text { removal. }\end{array}$ & $120-206[38]$ & Yes & Yes \\
\hline
\end{tabular}

Table 2-2: Journal Impact Factors

\begin{tabular}{|l|l|l|l|}
\hline Journal Title & ISSN & Total Cites & Impact Factor \\
\hline $\begin{array}{l}\text { Environmental } \\
\text { Science Technology }\end{array}$ & $0013-936 X$ & 31409 & 3.592 \\
\hline Ground Water & $0017-467 X$ & 2110 & 1.116 \\
\hline $\begin{array}{l}\text { Ground Water } \\
\text { Monitor }\end{array}$ & $1069-3629$ & 354 & 0.570 \\
\hline $\begin{array}{l}\text { Journal of } \\
\text { Environmental } \\
\text { Engineering ASCE }\end{array}$ & $0733-9372$ & 2190 & 0.727 \\
\hline $\begin{array}{l}\text { Journal of Hazardous } \\
\text { Material }\end{array}$ & $0304-3894$ & 1496 & 1.099 \\
\hline
\end{tabular}




\subsection{References}

1. $\quad$ EPA, Field Applications of In Situ Remediation Technologies: chemical oxidation. 1998: Washington DC.

2. $\quad$ ESTCP, E.T.S.C.P., Technology Status Review In Situ Oxidation. 1999.

3. Group, I.T.a.R.C.W. and I.S.C.O.W. Team, Technical and Regulatory Guidance for In Situ Chemical Oxidation of Contaminated Soil and Groundwater Technical/Regulatory Guidelines. 2001, Interstate Technology and Regulatory Council (ITRC): Washington DC.

4. $\quad$ Prenafeta-Boldu, F.X., et al., Bioremediation of BTEX hydrocarbons: Effect of soil inoculation with the toluene-growing fungus Cladophialophora sp. strain T1. Biodegradation, 2004. 15(1): p. 59-65.

5. Xu, Z., A. Mulchandani, and W. Chen, Detection of Benzene, Toluene, Ethyl Benzene, and Xylenes (BTEX) Using Toluene Dioxygenase-Peroxidase Coupling Reactions. Biotechnology Progress, 2003. 19(6): p. 1812-1815.

6. $\quad$ Prenafeta-Boldu, F.X., et al., Substrate interactions during the biodegradation of benzene, toluene, ethylbenzene, and xylene (BTEX) hydrocarbons by the fungus Cladophialophora sp. strain T1. Applied and Environmental Microbiology, 2002. 68(6): p. 2660-2665.

7. Beller, H.R., Analysis of benzylsuccinates in groundwater by liquid chromatography/tandem mass spectrometry and its use for monitoring in situ BTEX biodegradation. Environmental Science and Technology, 2002. 36(12): p. 2724-2728.

8. Montgomery, M.T., et al., Bacterial production stimulated across the zone of influence of a ground water circulation well in a BTEX-contaminated aquifer. Ground Water Monitoring and Remediation, 2002. 22(3): p. 144-150.

9. Schreiber, M.E. and J.M. Bahr, Nitrate-enhanced bioremediation of BTEX-contaminated groundwater: Parameter estimation from natural-gradient tracer experiments. Journal of Contaminant Hydrology, 2002. 55(1-2): p. 29-56.

10. Eckert, P. and C.A.J. Appelo, Hydrogeochemical modeling of enhanced benzene, toluene, ethylbenzene, xylene (BTEX) remediation with nitrate. Water Resources Research, 2002. 38(8): p. 51-511.

11. Cunningham, J.A., et al., Enhanced in situ bioremediation of BTEX-contaminated groundwater by combined injection of nitrate and sulfate. Environmental Science and Technology, 2001. 35(8): p. 1663-1670.

12. Durant, L.P.W., P.C. D'Adamo, and E.J. Bouwer, Aromatic hydrocarbon biodegradation with mixtures of as electron acceptors. Environmental Engineering Science, 1999. 16(6): p. 487-500.

13. Scheutz, C., H. Mosbaek, and P. Kjeldsen, Attenuation of Methane and Volatile Organic Compounds in Landfill Soil Covers. Journal of Environmental Quality, 2004. 33(1): p. 61-71.

14. Elsner, M., et al., Mechanisms and Products of Surface-Mediated Reductive Dehalogenation of Carbon Tetrachloride by Fe(II) on Goethite. Environmental Science and Technology, 2004. 38(7): p. 2058-2066.

15. Witt, M.E., et al., Natural attenuation of chlorinated solvents at Area 6, Dover Air Force Base: Groundwater biogeochemistry. Journal of Contaminant Hydrology, 2002. 57(1-2): p. 61-80. 
16. Rogers, S.W., et al., Natural attenuation of polycyclic aromatic hydrocarboncontaminated sites: Review. Practice Periodical of Hazardous, Toxic, and Radioactive Waste Management, 2002. 6(3): p. 141-155.

17. Borden, R.C., Natural bioattenuation of anaerobic hydrocarbons and chlorinated solvents in groundwater. Manuals and Reports on Engineering Practice, American Society of Civil Engineers, 2001(100): p. 121-151.

18. Azadpour-Keeley, A., et al., Monitored natural attenuation of contaminants in the subsurface: Processes. Ground Water Monitoring and Remediation, 2001. 21(2): p. 97107.

19. Yager, R.M., et al., Metabolic adaptation and in situ attenuation of chlorinated ethenes by naturally occurring microorganisms in a fractured dolomite aquifer near Niagara Falls, New York. Environmental Science and Technology, 1997. 31(11): p. 3138-3147.

20. Kim, H., et al., Surfactant-Enhanced Air Sparging in Saturated Sand. Environmental Science and Technology, 2004. 38(4): p. 1170-1175.

21. Rogers, S.W., K.-P. Chao, and S.K. Ong, Benzene nonaqueous phase liquids removal under air-sparged conditions. Journal of Environmental Engineering, 2004. 130(7): p. 751-758.

22. Adams, J.A. and K.R. Reddy, Extent of benzene biodegradation in saturated soil column during air sparging. Ground Water Monitoring and Remediation, 2003. 23(3): p. 85-94.

23. Reddy, K.R. and J.A. Adams, Effects of soil heterogeneity on airflow patterns and hydrocarbon removal during in situ air sparging. Journal of Geotechnical and Geoenvironmental Engineering, 2001. 127(3): p. 234-247.

24. Kirtland, B.C., C.M. Aelion, and M.A. Widdowson, Long-term AS/SVE for petroleum removal in low-permeability Piedmont saprolite. Journal of Environmental Engineering, 2001. 127(2): p. 134-144.

25. Murray, W.A., et al., Site 5 air sparging pilot test, Naval Air Station Cecil Field, Jacksonville, Florida. Journal of Hazardous Materials, 2000. 72(2-3): p. 121-145.

26. Rogers, S.W. and S.K. Ong, Influence of porous media, airflow rate, and air channel spacing on benzene NAPL removal during air sparging. Environmental Science and Technology, 2000. 34(5): p. 764-770.

27. Adams, J.A. and K.R. Reddy, Removal of dissolved-and free-phase benzene pools from ground water using in situ air sparging. Journal of Environmental Engineering, 2000. 126(8): p. 697-707.

28. Reddy, K.R. and J.A. Adams, Effect of groundwater flow on remediation of dissolvedphase VOC contamination using air sparging. Journal of Hazardous Materials, 2000. 72(2-3): p. 147-165.

29. Braida, W. and S.K. Ong, Influence of porous media and airflow rate on the fate of NAPLs under air sparging. Transport in Porous Media, 2000. 38(1-2): p. 29-42.

30. Johnston, C.D., et al., Volatilisation and biodegradation during air sparging of dissolved BTEX-contaminated groundwater. Journal of Contaminant Hydrology, 1998. 33(3-4): p. 377-404.

31. Johnston, C.D., et al., Volatilization and biodegradation during air sparging of a petroleum hydrocarbon-contaminated sand aquifer. IAHS Publication (International Association of Hydrological Sciences), 1998(250): p. 125-131. 
32. Wilson, D.J., et al., Groundwater cleanup by in-situ sparging. XIII. Random air channels for sparging of dissolved and nonaqueous phase volatiles. Separation Science and Technology, 1997. 32(18): p. 2969-2992.

33. Brooks, M.C., et al., Controlled release, blind test of DNAPL remediation by ethanol flushing. Journal of Contaminant Hydrology, 2004. 69(3-4): p. 281-297.

34. Chu, M., P.K. Kitanidis, and P.L. McCarty, Possible factors controlling the effectiveness of bioenhanced dissolution of non-aqueous phase tetrachloroethene. Advances in Water Resources, 2004. 27(6): p. 601-615.

35. Chrysikopoulos, C.V. and E.T. Vogler, Acoustically enhanced multicomponent NAPL ganglia dissolution in water saturated packed columns. Environmental Science and Technology, 2004. 38(10): p. 2940-2945.

36. Jeong, S.-W., A.L. Wood, and T.R. Lee, Enhanced removal of DNAPL trapped in porous media using simultaneous injection of cosolvent with air: Influencing factors and removal mechanisms. Journal of Hazardous Materials, 2003. 101(2): p. 109-122.

37. Saenton, S., et al., Effects of source zone heterogeneity on surfactant-enhanced NAPL dissolution and resulting remediation end-points. Journal of Contaminant Hydrology, 2002. 59(1-2): p. 27-44.

38. EPA, FRTR Remediation Technologies Screening Matrix and Reference Guide, Version 4.0.

39. Walden, T., Summary of processes, human exposure and technologies applicable to low permeability soils. American Petroleum Institute Soil and Groundwater Research Bulletin, 1995. 4631(August): p. 1.

40. Walden, T. and D.B. McWhorter, Assement of human exposure posed by LNAPLS in low permeability soils. American Petroleum Institute Soil and Groundwater Research Bulletin, 1995. 4631(August): p. B-1.

41. Kiker, G.A., et al., Application of Multicriteria Decision Analysis in Environmental Decision Making. Integrated Environmental Assessment and Management, 2005. 1(2): p. 95-108.

42. Udell, K.S., Thermal technologies in low permeability soils. American Petroleum Institute Soil and Groundwater Research Bulletin, 1995. 4631(August): p. G-1.

43. Beyke, G.F., David, Enhanced removal of separate phase viscous fuel by electrical resistance heating and multi-phase extraction, Thermal Remediation Services Inc. p. 1-7.

44. Bowles, M.W., et al., In situ ground water remediation using the trench and gate system. Ground Water, 2000. 38(2): p. 172-181.

45. Sutherson, S., S., Remediation Engineering Design Concepts. 1997, Boca Raton: Lewis Publishers. 362.

46. Miller, R.R., Bioslurping, in Technology Overview Report. 1996, GWRTAC: Pittsburgh. p. 10.

47. Roy F. Weston, I., Remediation Technologies Screening Matrix and Reference Guide. 1994.

48. Cagle, G.A., et al. Combining in situ technologies in low-permeability soil, a case study. in Proceedings of the 1997 ASCE Annual Fall National Convention, Oct 5-8 1997. 1997. Minneapolis, MN, USA: ASCE, New York, NY, USA.

49. Schwarzenbach, R.P., P.M. Gschwend, and D.M. Imboden, Environmental Organic Chemistry. Second Edition. 2003, Hoboken, NJ: John Wiley \& Sons, Inc. 1313. 
50. Ravens, T.M. and P.M. Gschwend, Surfactant-enhanced soil flushing in low permeability media. American Petroleum Institute Soil and Groundwater Research Bulletin, 1995. 4631(August): p. H-1.

51. Casagrande, I.L., Electro-osmosis in soils. Geotechnique, 1949. 1(3): p. 159-177.

52. Ko, S.-O., M.A. Schlautman, and E.R. Carraway, Cyclodextrin-enhanced electrokinetic removal of phenanthrene from a model clay soil. Environ. Sci. Technol, 2000. 34(8): p. 1535-1541.

53. Saichek, R.E. and K.R. Reddy, Effect of $\mathrm{pH}$ control at the anode for the electrokinetic removal of phenanthrene from kaolin soil. Chemosphere, 2003. 51(4): p. 273-287.

54. Venkatraman, S.N., et al. Integration of pneumatic fracturing with bioremediation for the enhanced removal of BTX from low permeability gasoline-contaminated soils. in Proceedings of the National Conference on Innovative Technologies for Site Remediation and Hazardous Waste Management, Jul 23-26 1995. 1995. Pittsburgh, PA, USA: ASCE.

55. Frank, U. and N. Barkley, Remediation of low permeability subsurface formations by fracturing enhancement of soil vapor extraction. Journal of Hazardous Materials, 1995. 40(2): p. 191-201.

56. Ding, Y., J.R. Schuring, and P.C. Chan, Volatile contaminant extraction enhanced by pneumatic fracturing. Practice Periodical of Hazardous, Toxic, and Radioactive Waste Management, 1999. 3(2): p. 69-76.

57. Roote, D.S., Technology Status Report Hydraulic, Pneumatic and Blast-Enhanced Fracturing. 2000, Ground-Water Remediation Technologies Analysis Center: Pittsburgh. p. 116.

58. Lowry, W., et al. Barometric Pumping with a Twist: VOC Containment and Remediation Without Boreholes. in Environmental Technology Development Through Industry Partnership. 1995. Morgantown, West Virginia.

59. Tillman, F.D.J. and J.A. Smith, Design and laboratory testing of a chamber device to measure total flux of volatile organic compounds from the unsaturated zone under natural conditions. Journal of Contaminant Hydrology, 2004. 75(1-2)): p. 71.

60. ISI Journal Citation Reports. 2004, Thomson Corporation.

61. Franzmeier, D.P., G.C. Steinhardt, and D.G. Schulze, Indiana Soil and Landscape Evaluation Manual. Vol. Version 1.0: Purdue University. 65. 


\section{Chapter 3. Regulatory Discussion on Technology Use}

\subsection{Introduction}

The use of new and innovative technologies is applicable only if they are economical and accepted by the governing regulatory agency. In Indiana IDEM is the regulatory body. A series of questions posed by the authors were answered by the staff of IDEM and communicated through Mike Sickles, Technical Environmental Specialist.

IDEM states that: Source removal is expensive; however, it is the fastest and most definitive method of contaminant removal. Perhaps the reason it is used at most INDOT sites, is that contaminated sites are usually found by INDOT as part of road construction and improvement projects. Because of the scheduling of their projects, there is usually not sufficient time for other remediation methods. A road widening project, for example, cannot be held off for five years to operate an SVE system or while a demonstration of monitored natural attenuation is made. The following are answers to your specific questions.

\subsection{Soil Fracturing}

Questions: What is IDEM's stance on Soil Fracturing as a tool for environmental remediation? Can it be used? Do you have any sites where this technology has been or will be used? Answer: Fracturing is a technology that was developed for deep bedrock environments, and is not expected to work well in shallow unconsolidated deposits, that typically are present in "low permeability soils". In shallow soil, fractures will run to the surface, not necessarily along contaminant migration pathways. In addition, in wet clayey soils the fractures will quickly become sealed once the pressure is removed. I am familiar with one remediation site in Indiana where this was tried, and it was not successful.

\subsection{Trench and Gate}


Questions: What is IDEM's stance on Trench and Gate or Funnel and Gate technologies for environmental remediation? Can it be used? Do you have any sites where this technology has been or will be used?

Answer: Funnel and gate is more of a groundwater containment and treatment method, and does not reduce contaminant concentrations in source areas. This method depends on groundwater flow and is not expected to be successful in low permeability environments with low groundwater flow rates. Although this method may be used to prevent contaminated groundwater from migrating, it will be a long-term remediation method, presumably not appropriate for INDOT sites on a fixed schedule.

\subsection{Thermal Technologies}

Questions: What is IDEM's stance on thermal technologies (Electrical Resistance Heating) for environmental remediation? Can it be used? Do you have any sites where this technology has been or will be used?

Answers: Thermal technologies, specifically ERH can be very effective, but are very expensive. It is most effective on volatile compounds, so it is not clear how effective they would be on older hydrocarbon sites, or sites with less volatile, heavier hydrocarbons. We have one site (volatile chlorinated solvents) where they used ERH. The ERH contractor stated that the starting costs for ERH are about $\$ 500,000$ which usually is more than most dig and haul operations. The ERH contractor did say that they were interested in adapting the technology to smaller sites, but that the costs involved (not technical feasibility) would be the largest obstacle. In addition, there are safety issues associated with putting a huge amount of electrical current into the ground. ERH heats soils up to a temperature of about 100 degrees Centigrade, which has the potential to damage or destroy underground infrastructure such as plastic piping, cables, etc, and 
the temperatures involved have safety issues as well. Finally, ERH requires a soil venting system, likely with off-gas treatment.

\subsection{Barometric Pumping}

Questions: What is IDEM's stance on Barometric Pumping for environmental remediation? Can it be used? Do you have any sites where this technology has been or will be used?

Answer: No responses were received and I'm not up on this one.

\subsection{Alternative Technologies}

Question: Do you have any other suggested alternatives that Purdue could follow up on?

Answer: No in-situ remediation method is going to beat dig and haul for quick, definitive source removal, particularly in low-permeability soils. The next best method (if soil permeability is not too low) is high-vacuum multi-phase extraction (MPE). It is a well-known technology, and produces a relatively rapid response. Technological improvements to MPE worthy of research could include steam injection to increase volatility and stripping of hydrocarbons, injection and MPE recovery of surfactants (an active area of research for NAPLs) or injection and MPE recovery of chemical oxidants. 


\section{Chapter 4: Remediation Decision Tree and Site Database}

Based on the literature survey and the case studies a decision trees was formulated for the remediation of aromatic hydrocarbons in low permeability soils (Fig 4-1). Documentation for the decision tree is also included in this chapter, as well as the results of applying the decision tree to "test cases." The documentation provides an explanation as to how the questions were formulated, and why a “yes” or “no” answer results in specific outcomes.

\subsection{SVE with Pneumatic Fracturing Decision Path}

Numbering and explanation comes from the master decision tree (Fig 4-1). Use of the decision path may be more understandable if the user follows the path in reverse.

i) In higher permeability soils there are many more proven technologies that are applicable.

ii) If the depth to groundwater is less than three feet, then the SVE system will pull water and less air, thereby reducing the efficiency of the system. A dual phase system may be more applicable in these conditions.

iii) Not applicable to SVE, since remediation is in the vadose zone. However as depth increases, cost is likely to go up as there is more material to remove, etc.

iv) If there is free product greater than 6 inches then other complementary free product recovery technologies (bioslurping) may be needed.

ix) If there is free product between 2 to 6 inches, then cheaper free product recovery technologies (bailers) are needed.

xi) If underground structures are present then the installation of piping may be limited. Since horizontal SVE wells are installed at shallow depths (less than 5 
Figures and Tables

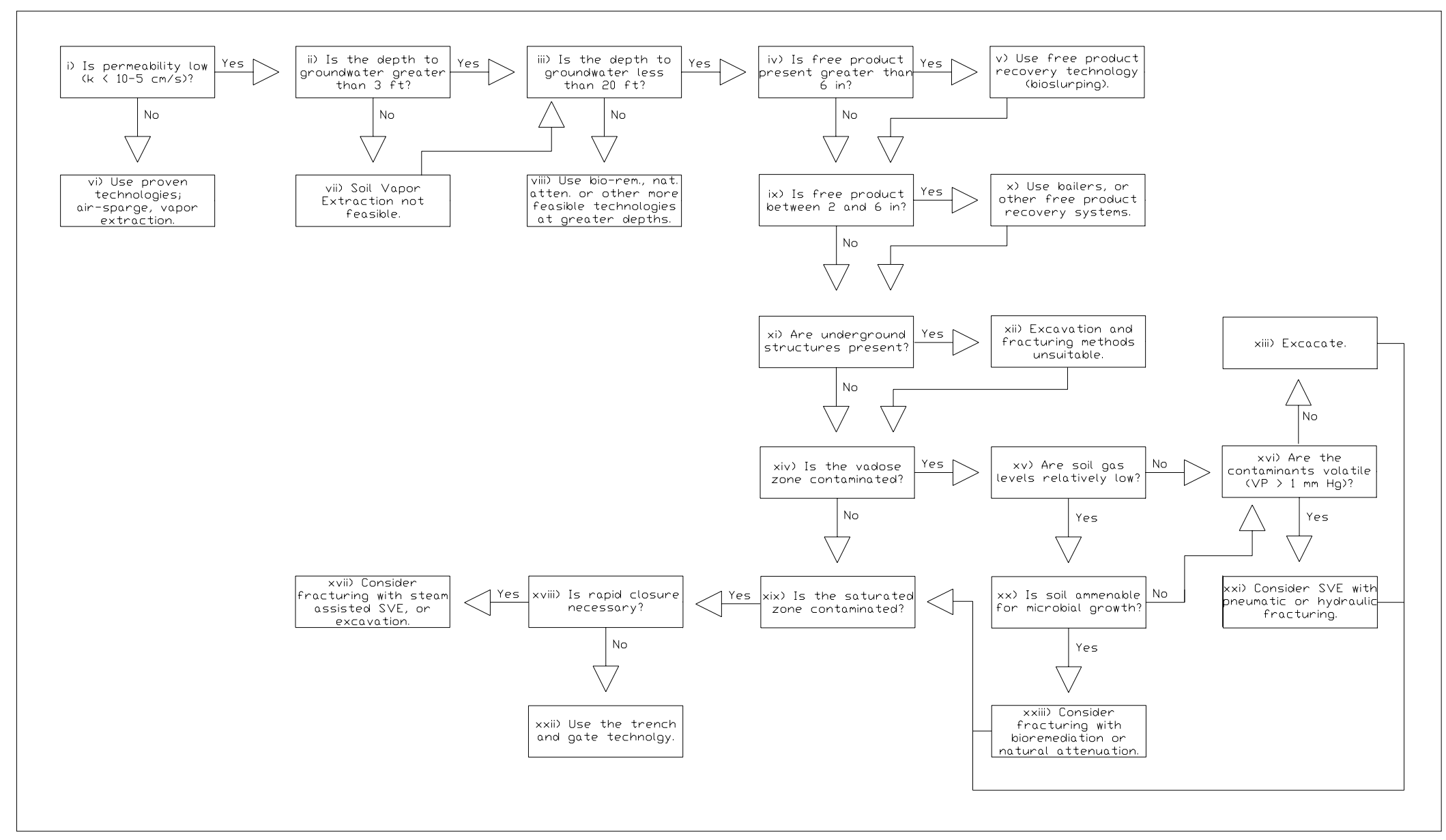

Fig 4-1: Technology Decision Tool for Remediation of BTEX in Low Permeability Soils 
feet) it may be possible to lay the pipe above underground structures. Vertical wells may not be applicable in areas with underground structures.

xii) Fracturing is not suitable in areas with underground structures.

xiv) SVE works the best in the unsaturated zone since it removes vapors. It can be used to remediate groundwater as well; however it does not work as efficiently.

$\mathrm{xv)}$ If the levels are low and the soil is amenable for bioremediation then bioremediation would be the technology of choice due to its low cost and minimal site disturbance. The construction of SVE systems requires the temporary closing of certain areas during construction.

xvi) The vapor pressure needs to be significant (VP $>1 \mathrm{~mm} \mathrm{Hg}$ ) for SVE to remove the contaminants.

xix) If the saturated zone is not contaminated then

\section{SVE with Pneumatic Fracturing is applicable in these conditions.}

\subsection{Trench and Gate Decision Path}

Numbering and explanation comes from the master decision tree.

i) In higher permeability soils there are many more proven technologies that are applicable.

ii) Not applicable to trench and gate.

iii) If the depth to groundwater is greater than 20 feet or the depth that a backhoe can dig, than other more expensive equipment is needed to install the tile drainage.

iv) If there is free product greater than 6 inches then other complementary free product recovery technologies (bioslurping) may be needed. 
ix) If there is free product between 2 to 6 inches, then cheaper free product recovery technologies (bailers) are needed.

xi) If underground structures are present then the installation of piping may be limited. Since horizontal SVE wells are installed at shallow depths (less than 5 feet) it may be possible to lay the pipe above underground structures. Vertical wells may not be applicable in areas with underground structures.

xii) Fracturing is not suitable in areas with underground structures.

xiv) Trench and Gate works to remediate contaminated groundwater. Therefore the vadose zone will need to be treated via alternative technologies (fracturing and SVE or bioremediation).

xix) Trench and Gate is applicable to remediate contaminated groundwater.

xviii) Rapid closure is not possible since trench and gate depends on the flow of groundwater. The addition of down gradient pumps can speed up the flow.

xxii) Trench and Gate is a technology that is applicable in these conditions.

\subsection{Bioremediation Decision Path}

i) In higher permeability soils there are many more proven technologies that are applicable.

ii) Not applicable for bioremediation.

iii) Not applicable for bioremediation.

iv) If there is free product greater than 6 inches than other complementary free product recovery technologies (bioslurping) may be needed. 
ix) If there is free product between 2 to 6 inches, then cheaper free product recovery technologies (bailers) are needed.

xi) If underground structures are present then test drilling and "nutrient” wells are not feasible in the areas with underground structures.

xiv) Bioremediation works best in the vadose zone. Both aerobic and anaerobic microbes work to degrade organic contaminants.

xv) If the amount of contamination is too high, then the microbes are not able to survive and degrade the contaminants.

xx) Test cultures need to be examined to see if the environment is suitable for microbial degradation.

xxiii) If the above criteria are met, then bioremediation is suitable in these conditions.

\subsection{Excavation Decision Path}

i) In higher permeability soils there are many more proven technologies that are applicable.

ii) Not applicable for excavations.

iii) If the depth to groundwater is greater than 20 feet or the depth that a backhoe can dig, than other more expensive equipment is needed to remove the contaminated soil / water.

iv) If there is free product greater than 6 inches than other complementary free product recovery technologies (bioslurping) may be needed. 
ix) If there is free product between 2 to 6 inches, then cheaper free product recovery technologies (bailers) are needed.

xi) If underground structures are present then excavation and other subsurface disturbances are not applicable in the areas with underground structures.

xiv) Excavation is applicable in the vadose zone.

$\mathrm{xv)}$ If the soil gas levels are low, then other technologies are likely to be used.

xvi) If the soil gas is not volatile or amenable by microbes then excavation is applicable.

xix) Excavation is applicable in the saturated zone.

xviii) Rapid closure is possible with excavation because of the large amount of material and contaminants removed in a matter of days or weeks. However, economics and above ground processes (what to do with the removed material) will determine how much material is removed.

xvii) Excavation is applicable to most remediation sites.

\subsection{Application of Decision Tree to Test Site}

\subsubsection{Site: East Garrington Study Site}

Location: Red Deer County, Alberta, Canada

(add superscripts to all numbers highlighted in green)

i) Is permeability low $\left(\mathrm{k}<10^{-5} \mathrm{~cm} / \mathrm{s}\right)$ ?

Answer: Yes, $\mathrm{k}=10^{-10} \mathrm{~m} / \mathrm{s}$ in the shale bedrock to $2 \times 10^{-5} \mathrm{~m} / \mathrm{s}$ in tills containing discontinuous sandy stringers or fractures

ii) Is the depth to groundwater greater than 3 feet?

Answer: Yes, depths range from 1 to 2 meters $=3.28$ to 6.56 feet 
iii) Is the depth to groundwater less than 20 feet?

Answer: Yes, depths range from 1 to 2 meters $=3.28$ to 6.56 feet

iv) Is free product present greater than 6 inches?

Answer: No, free product was not encountered at this site.

ix) Is free product between 2 and 6 inches?

Answer: No, free product was not encountered at this site.

xi) Are underground structures present?

Answer: No underground structures are present in the contaminated area.

xiv) Is the vadose zone contaminated?

Answer: The vadose was not contaminated at this site.

xix) Is the saturated zone contaminated?

Answer: Yes, the saturated zone is contaminated.

xviii) Is rapid closure necessary?

Answer: No, it is not.

xxii) Result: Use Trench and Gate Remedial System

\subsubsection{Decision Tree Test Case - Bioremediation and Pneumatic Fracturing}

Site: Delaware Valley Refinery

Location: Delaware Valley

i) Is permeability low $\left(\mathrm{k}<10^{-5} \mathrm{~cm} / \mathrm{s}\right)$ ?

Answer: Yes, clayey silts; surficial fill 1-4 ft, stiff orange-tan clayey silt to 9-12 ft, grading into silty sand at 9-10 ft

ii) Is the depth to groundwater greater than 3 feet? 
Answer: Yes, water table located at 13-15 ft bgs.

iii) Is the depth to water less than 20 feet?

Answer: Yes, water table located at 13-15 ft bgs.

iv) Is free product present greater than 6 inches?

Answer: No, free product was not encountered at this site.

ix) Is free product between 2 and 6 inches?

Answer: No, free product was not encountered at this site.

xi) Are underground structures present?

Answer: No, no underground structures are present in the contaminated area.

xiv) Is the vadose zone contaminated?

Answer: Yes, the vadose zone is contaminated.

xv) Are soil gas levels relatively low?

Answer: Yes

$\mathrm{xx}$ ) Is the soil amenable for microbial growth?

Answer: Yes, plate counts indicated the presence of heterotrophic microorganisms of which roughly $40 \%$ were denitrifiers.

xxiii) Result: Use Pneumatic Fracturing with Bioremediation

\subsubsection{Decision Tree Test Case - Soil Vapor Extraction and Pneumatic Fracturing}

Site: Tinker Air Force Base

Location: Oklahoma City, OK

i) Is permeability low $\left(\mathrm{k}<10^{-5} \mathrm{~cm} / \mathrm{s}\right)$ ? 
Answer: Yes, Upper $10 \mathrm{ft}$ of soil are primarily weathered red clays, clay backfill and sandy gravel were found at some locations at $15 \mathrm{ft}$, grades into a sandy unit below the upper clay, cemetation of the sands begins at $20 \mathrm{ft}$ and increases with depth.

ii) Is the depth to groundwater greater than 3 feet?

Answer: Yes

iii) Is the depth to water less than 20 feet?

Answer: Yes

iv) Is free product present greater than 6 inches?

Answer: No, free product was not encountered at this site.

ix) Is free product between 2 and 6 inches?

Answer: No, free product was not encountered at this site.

xi) Are underground structures present?

Answer: No underground structures are present in the contaminated area.

xiv) Is the vadose zone contaminated?

Answer: Yes, the vadose zone is contaminated.

xv) Are soil gas levels relatively low?

Answer: Yes

$\mathrm{xv}$ ) Is the soil amenable for microbial growth?

Answer: No data.

xvi) Are the contaminants volatile?

Answer: Yes.

xxi) Result: Use Soil Vapor Extraction and Pneumatic Fracturing 


\subsubsection{Decision Tree Test Case - Bioremediation and Pneumatic Fracturing}

Site: Denver Federal Center

Location: Denver, CO

i) Is permeability low $\left(\mathrm{k}<10^{-5} \mathrm{~cm} / \mathrm{s}\right)$ ?

Answer: Yes, tightly packed clays.

ii) Is the depth to groundwater greater than 3 feet?

Answer: No data, assumed to be yes.

iii) Is the depth to water less than 20 feet?

Answer: No data, assumed to be yes.

iv) Is free product present greater than 6 inches?

Answer: No, free product was not encountered at this site.

ix) Is free product between 2 and 6 inches?

Answer: No, free product was not encountered at this site.

xi) Are underground structures present?

Answer: No underground structures are present in the contaminated area.

xiv) Is the vadose zone contaminated?

Answer: Yes, the vadose zone is contaminated.

xv) Are soil gas levels relatively low?

Answer: Yes

$\mathrm{xx}$ ) Is the soil amenable for microbial growth?

Answer: Yes, plate counts indicated the presence of heterotrophic microorganisms of which roughly $40 \%$ were denitrifiers.

xxiii) Result: Use Pneumatic Fracturing with Bioremediation 


\subsection{Summary of Data in Database}

The database includes numerous categories that include; Site Name, Location, Technology(ies) Used, Study Size, Timeframe, Geology, Hydrogeology, Goals, Results, Contaminants Present, Contaminant Levels, Document Title, Author(s), FID \#, Incident \#.

The subsurface of many sites in the database are located in glacial till. They vary from clays to silty clays with lenses of sand and gravel. One site is located in saprolite and another in marl. All sites in the database have low permeability soils $\left(\mathrm{k}<10^{-5} \mathrm{~cm} / \mathrm{s}\right)$. The goal of the sites evaluated at the field scale was to remediate the soil and groundwater to regulatory levels. Studies in the laboratory or pilot scale were to evaluate the feasibility of using the technology.

Results varied from being effective to not being effective. All sites contained BTEX, some also contained PAHs, MTBE or chlorinated solvents. Contaminant levels varied from sites with pure product to sites with benzene concentration as low as $0.019 \mathrm{mg} / \mathrm{L}$. Sites in Indiana have FID numbers and incident numbers. Sites from other areas do not. There are eight sites from Indiana and fourteen from other regions. 
Fig 4-2: Sample page from remediation site database

\begin{tabular}{|c|l|l|l|}
\hline ID & Site Name & Site Location & Technology (ies) Used \\
\hline 16 & Indianapolis NW (Marathon \# 2015) & Indianapolis, IN & $\begin{array}{l}\text { Excavation followed by ORC } \\
\text { injections. }\end{array}$ \\
\hline
\end{tabular}

\begin{tabular}{|l|l|l|l|}
\hline Study Size & Timeframe & Geology & Hydrogeology \\
\hline Field Scale & years & $\begin{array}{l}\text { Silty clay to clayey silt to 8-12 ft, a thin }(1-3 \mathrm{ft}) \text { silty } \\
\text { sand zone underlies the silty clay, followed by a } \\
\text { hard, clayey silt unit to } 16 \mathrm{ft}\end{array}$ & $\begin{array}{l}\text { local GW flow is generally } \\
\text { to the south }\end{array}$ \\
\hline
\end{tabular}

\begin{tabular}{|l|l|l|}
\hline Goals & Results & Contaminants Present \\
\hline $\begin{array}{l}\text { Remediate TPH levels below } 100 \mathrm{mg} / \mathrm{kg} \text {. (IN } \\
\text { regulatory levels). }\end{array}$ & $\begin{array}{l}\text { Benzene level dropped to 1.75 mg/L } \\
\text { after 24 months, no increase in DO. }\end{array}$ & BTEX \\
\hline
\end{tabular}

\begin{tabular}{|l|l|l|}
\hline Contaminant Levels & Document Title & Author(s) \\
\hline $\begin{array}{l}\text { Pre ORC Injections 3.7 } \\
\text { (mg/L) benzene }\end{array}$ & IDEM Public Files \& Surgical Site Closure - Integrating & Steven P. Sittler, P.G. \\
Natural Attenuation and Focused Source Treatment & (Handex - Indianapolis, IN) \\
\hline
\end{tabular}

\begin{tabular}{|l|l|}
\hline FID \# & Incident \# \\
\hline 5399 & 199708519 \\
\hline
\end{tabular}

